\title{
Hubungan Persepsi, Dukungan Keluarga dan Akses Pelayanan terhadap Partisipasi Pria dalam Keluarga Berencana
}

\author{
Meinasari Kurnia Dewi, ${ }^{1}$ Fira Rahmawati ${ }^{2}$ \\ ${ }^{1,2}$ Program Studi Kebidanan Program Sarjana Terapan Sekolah Tinggi Ilmu Kesehatan Indonesia Maju \\ Jln. Harapan nomor 50, Lenteng Agung-Jakarta Selatan 12610 \\ Telp: (021) 78894045, Email : meinasarikurnidewi@gmail.com, firarahmawati09@gmail.com
}

\begin{abstract}
Abstrak
Partisipasi pria dalam keluarga keluarga berencana adalah salah satu tanggung jawab Pria/ suami dalam kesertaan ber-KB, serta berperilaku seksual yang sehat dan aman bagi dirinya, pasangan dan keluarganya. Tujuan penelitian ini untuk mengetahui hubungan persepsi, dukungan keluarga dan akses pelayanan terhadap partisipasi pria keluarga berencana di wilayah kerja Puskesmas Sukamanah Kec. Megamendung Bogor Jawa Barat Tahun 2017. Penelitian ini menggunakan desain deskriptif anakitik dengan pendekatan Cross Sectional. menggunakan desain deskriptif analitik, pendekatan cross sectional, Metode Acidental Sampling dengan sampel sebanyak 90 responden. Populasi penelitian adalah seluruh pria pasangan usia subur yang Keluarga Berencana. Penelitian ini menggunakan data primer. Hasil analisa bivariat menggunakan uji Chi Square dengan $\alpha 5 \%$ diperoleh persepsi $\rho$-value $=0,009$ dan OR 3,500, dukungan keluarga $\rho$-value $=0,001$ dan OR 4,884 dan Akses pelayanan $\rho$-value $=0,010$ dan OR 3,667. Kesimpulan terdapat hubungan persepsi, dukungan keluarga dan akses pelayanan terhadap partisipasi pria keluarga berencana diwilayah kerja Puskesmas Sukamanah Kec. Megamendung Bogor Jawa Tahun 2017, saran kepada Puskesmas, diharapkan untuk terus berkoordinasi dalam hal peningkatan jumlah keder kesehatan yang menangani bidang KB dan bagi petugas lapangan keluarga berencana (PLKB) untuk lebih aktif mendatangi rumah-rumah warga dalam memberi penyuluhan atau penjelasan tentang efek samping yang ditimbulkan oleh alat kontrasepsi, bahwa hal tersebut merupakan hal yang biasa diatasi.
\end{abstract}

Kata Kunci : Akses Pelayanan, Dukungan keluarga, Partisipasi, Persepsi

\begin{abstract}
Men's participation in family planning is one of the responsibilities of men or husbands in family planning, as well as safe and healthy sexual behavior for themselves, spouse and family. The purpose of this research is to know the relation of perception, family support and access to family planning participation in work area of Sukamanah Public Health Center of Megamendung Subdistrict, Bogor, West Java Year 2017. This research used descriptive design of children with Cross Sectional approach. Accidental Sampling method with a sample of 90 respondents. The study population was all male of fertile-age couples with family planning. This study used primary data. The result of bivariate analysis using Chi Square test with $\alpha 5 \%$ improvement of perception $\rho$ value $=0,009$ and $O R$ 3,500, family support value $=0,001$ and $O R$ 4,884 and access service $\rho$-value $=0,010$ and OR 3,667. Conclusions of health, family relations and access to Sukamanah Public Health Center of Megamendung Subdistrict, Bogor, West Java Year 2017, suggestions to the Puskesmas, are expected to continue to coordinate in terms of increasing the number of health departments that handle family planning and for family planning field officers (PLKB) to more actively visit the homes of citizens in giving counseling or explanation about the side effects caused by contraceptives, that it is a common thing to overcome.
\end{abstract}

Keywords: Service Access, Family Support, Participation, Perception 


\section{Pendahuluan}

Meningkatkan kesehatan individu, keluarga dan masyarakat beserta lingkungannya merupakan salah satu misi pembangunan kesehatan maju Indonesia sehat dan salah satu untuk rencana pencapaian adalah dengan meningkatkan kesadaran, kemampuan hidup sehat dan kemampuan sehingga terwujudnya derajat kesehatan masyarakat yang optimal melalui terciptanya masyarakat, Bangsa dan Negara Indonesia yang ditandai oleh penduduk hidup dalam lingkungan dan perilaku yang sehat, di seluruh wilayah Republik Indonesia memiliki kemampuan meningkatkan pelayanan kesehatan yang bermutu secara adil dan merata. ${ }^{1}$

Keluarga Berencana (KB) merupakan bentuk upaya mengatur kelahiran anak, jarak dan usia ideal melahirkan, mengatur kehamilan, melalui promosi, perlindungan dan bantuan sesuai hak reproduksi untuk mewujudkan keluarga yang berkualitas. Keluarga Berencana memungkinkan Pasangan Usia Subur untuk mengantisipasi kelahiran, mencapai jumlah anak yang mereka inginkan, dan mengukur jarak dan waktu kelahiran. ${ }^{2}$

Menurut Word Health Organization (WHO) 2014, bahwa pengguna kontrasepsi di Dunia telah meningkat, terutama di Asia, Amerika Latin dan terendah di Afrika, secara global, pengguna kontrasepsi modern telah meningkat sebanyak 54\% dan pada tahun 2014 sebanyak $75,4 \%$. Secara rasional Pasangan Usia Subur menggunakan metode kontrasepsi modern dan telah meningkat 6 tahun terakhir. Di Afrika dari 23,6\% menjadi 26,6\%, Asia dari 60,9 menjadi $61,6 \%$. Amerika Latin dan Karbia naik sedikit dari $66,7 \%$ menjadi $67,0 \% .^{3}$

Partisipasi pria atau suami dalam KB merupakan salah satu tanggung jawab pria/suami dalam kesertaan ber-KB, serta berperilaku seksual yang sehat dan aman bagi dirinya, pasangan dan keluarganya. Bentuk partisipasi pria atau suami dalam KB dapat dilakukan secara langsung dan tidak langsung. Partisipasi pria atau suami secara langsung (sebagai peserta Keluarga Berencana) adalah pria atau suami menggunakan salah satu cara atau metode pencegahan kehamilan, seperti kondom, vasektomi (kontap pria), serta Keluarga Berencana alamiah yang melibatkan pria/suami (metode sanggama terputus dan metode pantang berkala). ${ }^{4}$
Partisipasi laki-laki baik dalam praktek KB maupun dalam pemeliharaan Kesehatan Ibu dan Anak termasuk pencegahan kematian Maternal hingga saat ini masih rendah. Untuk menurunkan Angka Kematian Ibu, diperlukan gerakan nasional yang juga melibatkan semua pihak dengan program dan kegiatan yang komprehensif, terkait terukur dan seimbang yang pada akhirnya peran pria atau suami dalam program Keluarga Berencana akan mampu mendorong peningkatan kualitas pelayanan Keluarga Berencana, peningkatan kesetaraan dan keadilan gender, peningkatan penghargaan terhadap hak asasi manusia, dan berpengaruh positif dalam mempercepat penurunan angka kelahiran total (TFR), penurunan Angka Kematian Ibu (AKI), dan penurunan Angka Kematian Bayi (AKB). ${ }^{5}$

Berdasarkan hasil studi pendahuluan di Puskesmas Sukamanah didapat 2016 jumlah Kartu Keluarga 1802 jiwa dan jumlah PUS 1423 jiwa. Dalam setahun terdapat 116 pria yang ikut partisipasi Keluarga Berencana. Berdasarkan data diatas, penulis tertarik untuk melakukan penelitian tentang Hubungan Persepsi, Dukungan Keluarga dan Akses Pelayanan terhadap Partisipasi Pria dalam Keluarga Berencana.

Negara Indonesia keseluruhan cakupan Pasangan Usia Subur Baru dan Aktif sejumlah 48.536.690 jiwa. Indonesia Cakupan peserta baru Keluarga Berencana jumlah pasangan usia subur sebesar 48.536.690 jiwa alat kontrasepsi yang dipakai MOP $11.765(0,18 \%)$, dan kondom 318.625 (4.78\%). Sedangkan, peserta aktif Keluarga Berencana jumlah pasangan usia subur sebesar 7.129.900 jiwa. Alat kontrasepsi yang $\operatorname{MOP}(0,64 \%)$ dan kondom $74,80 \% .^{10}$

Di Jawa Barat keseluruhan cakupan pasangan usia subur baru dan aktif sejumlah 9.521.667 jiwa. Di Jawa Barat Cakupan Peserta Baru Keluarga Berencana jumlah Pasangan Usia Subur sebesar 2.284.821 jiwa. Alat kontrasepsi yang dipakai MOP 898 (0,26\%), Kondom 38.861 (11,09\%). Sedangkan, Peserta Aktif Keluarga Berencana jumlah Pasangan Usia Subur sebesar 7.129.900 (74,88\%). Alat kontrasepsi yang dipakai MOP $50.608(0,71 \%)$, dan Kondom $129.010(1,81 \%)^{11}$

Di Kota Bogor jumlah penduduk 43.920.043 jiwa di Tahun 2015 didapatkan PUS sebanyak 152.739 jiwa. IUD 1.147, MOW 174, MOP 12, kondom 295. Sedangkan prestasi 
persera KB dan bukan peserta KB $64,67 \%$, semua dengan cara modern $64.33 \%$ dan yang tidak pakai $35,33 \% .^{11}$

Menurut penelitian Matertha Hasian dengan judul faktor yang berhubugan dengan kepesertaan Pria dalam Program Keluarga Berencana di Wilayah Kerja Puskesmas Sei Jang Tanjung Pinang 2012 dengan menggunakan kuesioner pada 136 responden. Dengan hasil penelitian menunjukan bahwa $23,5 \%$ responden merupakan peserta Keluarga Berencana, serta adanya hubungan dan bermakna antara faktor pendidikan, dukungan istri, pengetahuan dan kepesertaan pria dalam program Keluarga Berencana, dengan desain penelitian menggunakan pendekatan cross sectional yang di laksanakan di Puskesmas Sei Jang Tanjung Pinang pada bulan April-Mei. ${ }^{17}$

Berdasarkan hasil studi pendahuluan di Puskesmas Sukamanah didapat 2016 jumlah Kartu Keluarga 1802 jiwa dan jumlah PUS 1423 jiwa. Dalam setahun terdapat 116 pria yang ikut partisipasi KB. Berdasarkan data diatas, penulis tertarik untuk melakukan penelitian tentang Hubungan Persepsi, Dukungan Keluarga dan Akses Pelayanan terhadap Partisipasi Pria dalam Keluarga Berencana. Dimana tidak ada peningkatan dan penurunan dari tahun sebelumnya.

Hal penting dalam Keluarga Berencana Partisipasi pria menjadi kesahatan reproduksi karena pria merupakan partner dalam reproduksi dan seksual sehingga sangat beralasan apabila pria dan wanita berbagi tanggung jawab dan peran secara seimbang untuk mencapai kepuasan kehidupan seksual dan berbagai beban untuk mencegah penyakit serta komplikasi Keluarga Berencana dan kesehatan reproduksi, dan pria bertanggung jawab secara sosial dan ekonomi termasuk untuk anaknya sehingga akan membentuk ikatan yang lebih kuat antara istri dan keturunannya.

Berdasarkan latar belakang diatas, maka dapat diangkat rumusan masalah sebagai berikut "Bagaimana Hubungan Persepsi, Dukungan Keluarga dan Akses Pelayanan terhadap Partisipasi Pria dalam Keluarga Berencana ?"

Tujuan Mengetahui Hubungan Persepsi, Dukungan Keluarga dan Akses Pelayanan terhadap Partisipasi Pria Keluarga Berencana di
Wilayah Kerja Puskesmas Sukamanah Kec. Megamendung Bogor Jawa Barat Tahun 2017.

\section{Metode}

Penelitian ini menggunakan metode deskriptif analitik yaitu suatu penelitian yang mencoba menggali bagaimana dan mengapa fenomena itu terjadi, selanjutnya melakukan analisis dinamika kolerasi antara fenomena tersebut. $^{13}$

Penelitian ini menggunakan rancangan cross sectional dimana penelitian cross sectional merupakan suatu penelitian untuk mempelajari dinamika kolerasi antara faktor-faktor resiko atau variabel independen dengan efek atau variabel dependen yang diobservasi atau pengumpulan datanya sekaligus pada suatu saat yang sama. ${ }^{14}$

Intrumen penelitian ini adalah alat-alat yang digunakan untuk pengumpulan data. Instrumen itu berupa kuesioner yang menggunakan skala likert. Penelitian ini adalah alat-alat yang digunakan untuk pengumpulan data. Instrumen itu berupa kuesioner yang menggunakan skala likert. ${ }^{14}$ Data yang diambil adalah data primer Responden diminta mengisi jawaban pertanyaan variabel hubungan persepsi, dukungan keluarga dan akses pelayanan terhadap partisipasi pria dalam keluarga berencana di wilayah Puskesmas Sukamanah Kec. Megamendung Bogor Jawa Barat Tahun 2017 dalam skala ordinal terbentuk variabel dengan alternatif atau katagotik jawabannya.

Instrumen yang digunakan dalam penelitian ini untuk mengetahui hubungan persepsi, dukungan keluarga dan akses pelayanan terhadap partisipasi pria dalam keluarga berencana yang memenuhi syarat validitas dan reliabilitas sehingga tidak ada perbaikan instrument lagi. ${ }^{14}$

Penelitian ini akan dilakukan di wilayah kerja Puskermas Sukamanah Kec. Megamendung Bogor Jawa Barat. Penelitian ini dilakukan pada Bulan Desember Tahun 2017.

Populasi dalam penelitian ini adalah seluruh PriaPasangan Usia Subur yang Kelurga Berencana di wilayah Kerja Puskesmas Sukamanah Kec. Megamendung Bogor Jawa Barat. Populasi penelitian sebanyak 116 responden. ${ }^{15}$ Sampel adalah sebagian dari populasi yang nilai atau karakteristiknya kita ukur yang nantinya kita pakai untuk 
menduga karakteristik dari populasi. ${ }^{14}$ Sampel dalam penelitian ini adalah Pria Pasangan Usia Subur yang Keluarga Berencana Bulan Desember Tahun 2017 sebanyak 90 orang dengan pengambilan sampel secara Accidental Sampling dimana pengambilan sampel yang didasarkan pada suatu responden yang kebetulan ada atau tersedia di suatu tempat sesuai dengan konteks penelitian.

Rumus slovin digunakan untuk menentukan ukuran sampel dari populasi yang telah diketahui jumlahnya yaitu sejumlah 116 orang. Berdasarkan Besarnya sampel dalam penelitian ini dihitung dengan menggunakan rumus slovin. Sebelum digunakan dalam penelitian, kuesioner yang berisi pertanyaan akan diisi oleh 20 responden. Dalam uji validitas dan uji reliabilitas ini akan diolah menggunakan SPSS 18.0 dan jika pertanyaan dalam instrumen tersebut dinyatakan tidak valid maka tidak boleh dituangkan dalam instrumen dari masing-masing variabel tersebut dan sebaliknya bila kuesioner valid maka dapat digunakan sebagai kuesioner penelitian.

Sedangkan dalam pengolahan data menggunakan metode analisis univariat dan analisis bivariat. Analisis univariat merupakan analisis yang dilakukan terhadap setiap variabel dari hasil penelitian yang menghasilkan gambaran distribusi dan presentasi dari setiap variabel dan analisis bivariat adalah penelitian yang dilakukan untuk mengetahui apakah ada hubungan antara dua variabel yaitu variabel dependen (terikat) dan independen (bebas). ${ }^{16}$ Sesuai hasil yang data dalam penelitian ini akan disajikan dalam bentuk distribusi frekuensi dari sampel penelitian. Data yang disajikan pada awal hasil analisis yaitu berbentuk gambaran atau deskripsi mengenai sampel, dimana penjelasan disertai dengan ringkasan yang berupa tabel dari deskripsi yang utama.

Hal ini dilakukan untuk mempermudah pembaca dalam mengenal karakteristik dari responden sesuai data yang suda diperoleh. Selanjutnya uji yang menggunakan adalah menggunakan uji chi- square yang bertujuan untuk mengetahui hubungan antara variabel independen (bebas) dengan dependen (terikat) dengan bantuan SPSS 18.0 yang disajikan dalam bentuk diagram, tabel dan interpretasi.

\section{Hasil}

\section{Analisis Univariat}

Tabel 1. Distribusi dan Frekuensi persepsi, dukungan keluarga, dan akses pelayanan keselahatan terhadap partisipasi pria dalam keluarga di wilayah kerja Pusksesmas megamendung bogor jawa barat tahun 2017

\begin{tabular}{lcc}
\hline Variabel & Frekuensi & $\begin{array}{c}\text { Presentase } \\
(\%)\end{array}$ \\
\hline Partisipsasi & 42 & 46,7 \\
Rendah & 48 & 53,3 \\
Tinggi & & \\
Persepsi & 50 & 50,6 \\
$\quad$ Buruk & 40 & 44,4 \\
$\quad$ Baik & \\
Dukungan Keluarga & & 56,7 \\
$\quad$ Tidak Mendukung & 51 & 43,3 \\
$\quad$ Mendukung & 39 & \\
Akses pelayanan & & 63,3 \\
$\quad$ Tidak Terjangkau & 57 & 36,7 \\
$\quad$ Terjangkau & 33 &
\end{tabular}

Sumber : Hasil olah data 2017

Hasil distribusi frekuensi menunjukan bahwa dari 90 responden didapatkan ada sebanyak 48 responden $(53,5 \%)$ memutuskan untuk memilih partisipasi tinggi dalam keluarga berencana dan ada sebanyak 42 responden $(46,7 \%)$ memutuskan untuk memilih partisipasi rendah dalam keluarga berencana. Hasil distribusi frekuensi menunjukan bahwa dari 90 responden didapatkan ada sebanyak 50 responden $(50,6 \%)$ memutuskan memilih persepsi buruk dalam keluarga berencana dan ada sebanyak 40 responden $(44,4 \%)$ memutuskan untuk memilih persepsi baik dalam keluarga berencana.

Hasil distribusi frekuensi menunjukan bahwa dari 90 responden didapatkan ada sebanyak 51 responden $(56,7 \%)$ memutuskan memilih tidak mendukung keluarga berencana dan didapatkan ada sebanyak 39 responden $(43,3 \%)$ memutuskan untuk memilih mendukung dalam keluarga berencana.

Hasil distribusi frekuensi menunjukan bahwa dari 90 respoonden didapatkan ada sebanyak 57 responden $(63,6 \%)$ memutuskan untuk memilih akses pelayanan yang tidak terjangkau dalam keluarga berencana dan ada sebanyak 33 responden (36,7\%) memutuskan untuk memilih akses pelayanan yang terjangkau dalam keluarga berencana. 


\section{Analisis Bivariat}

Analisa bivariat dilakukan untuk menguji hipotesa antara dua variabel yaitu hubungan variabel independen (bebas) dan variabel dependen (terikat) yang diduga memiliki hubungan dan kolerasi, maka uji yang dilakukan adalah menggunakan uji Chi-Square yaitu untuk menguji kemaknaan hubungan antara variabel independen dan variabel dependen dengan menggunakan derajat kepercayaan $\alpha(0,05)$. Apabila $\mathrm{P}$ value $<0,05$ maka ada hubungan antara variabel dependen (terikat) dan variabel independen (bebas). Uji ini akan membandingkan frekuensi yang terjadi (observation) dengan frekuensi harapan. ${ }^{14}$

Berdasarkan hasil analisa hubungan antara persepsi dengan partisipasi pria dalam keluarga berencana pada 90 responden diperoleh bahwa ada sebanyak 30 responden $(60,0 \%)$ dari 50 responden yang memiliki persepsi buruk dengan partisipasi rendah Sedangkan ada sebanyak 28 responden $(70,0 \%)$ dari 40 rensponden yang memiliki persepsi baik dengan partisipasi tinggi. Hasi uji statistik nilai $\rho$ value $=0,009$ dalam hal ini nilai $\alpha<0,05$ yaitu Ho di tolak dan pernyataan Ha di terima maka akan dapat disimpulkan bahwa ada hubungan antara persepsi dengan partisipasi pria dalam keluarga berencana. Dari hasil nilai Odd Rasio (OR) 95\% CI adalah sebesar 3,500 $(1,449-8,453)$ yang artinya responden yang memiliki persepsi buruk berpeluang 3,5 kali partisipasi pria dalam mengikuti keluarga berencana dibandingkan dengan responden yang memiliki persepsi baik. Berdasarkan hasil analisa hubungan antara dukungan keluarga dengan partisipasi pria dalam keluarga berencana pada 90 responden diperoleh bahwa ada sebanyak 32 responden $(62,7 \%)$ dari 51 responden yang dukungan keluarganya tidak mendukung dengan partisipasi rendah. Sedangkan ada sebanyak 29 responden $(74,4 \%)$ dari 39 rensponden yang dukungan keluarganya mendukung dengan partisipasi tinggi.

Hasi uji statistik nilai $\rho$ value $=0,001$ dalam hal ini nilai $\alpha<0,05$ yaitu Ho di tolak dan pernyataan Ha di terima maka akan dapat disimpulkan bahwa ada hubungan antara dukungan keluarga dengan partisipasi pria dalam keluarga berencana.Dari hasil nilai Odd Rasio (OR) 95\% CI adalah sebesar 4,884 $(1,954-12,206)$ yang artinya responden yang memiliki dukungan keluarga tidak mendukung berpeluang 4,8 kali partisipasi pria dalam mengikuti keluarga berencana dibandingkan dengan responden yang memiliki dukungan keluarga mendukung. Berdasarkan hasil analisa hubungan antara akses pelayanan dengan partisipasi pria dalam keluarga berencana pada 90 responden diperoleh bahwa ada sebanyak 33 responden $(57,9 \%)$ dari 57 responden yang memiliki akses pelayanan tidak terjangkau dengan partisipasi rendah. Sedangkan ada sebanyak 24 responden $(72,2 \%)$ dari 33 rensponden yang memiliki akses pelayanan terjangkau dengan partisipasi tinggi. Hasi uji statistik nilai $\rho$ value $=0,010$ dalam hal ini nilai $\alpha<0,05$ yaitu Ho di tolak dan pernyataan $\mathrm{Ha}$ di terima maka akan dapat disimpulkan bahwa ada hubungan antara akses pelayanan dengan partisipasi pria dalam keluarga berencana.

Tabel. 2 Hubungan Persepsi dengan Partisipasi Pria dalam Keluarga Berencana di Wilayah Kerja Puskesmas Sukamanah Kec. Megamendung Bogor Jawa Barat Tahun 2017

\begin{tabular}{|c|c|c|c|c|c|c|c|c|}
\hline \multirow{3}{*}{ Variabel } & \multicolumn{4}{|c|}{$\begin{array}{c}\text { Partisipasi Pria dalam Keluarga } \\
\text { Berencana }\end{array}$} & \multicolumn{2}{|c|}{ Total } & \multirow{3}{*}{ P Value } & \multirow{3}{*}{ OR } \\
\hline & \multicolumn{2}{|c|}{ Normal } & \multicolumn{2}{|c|}{ Tidak Normal } & \multirow{2}{*}{$\mathbf{F}$} & \multirow{2}{*}{$\%$} & & \\
\hline & $\mathbf{F}$ & $\%$ & $\mathbf{F}$ & $\%$ & & & & \\
\hline \multicolumn{9}{|l|}{ Persepsi } \\
\hline Buruk & 30 & 60,0 & 12 & 23,1 & 50 & 100 & \multirow[t]{2}{*}{0,009} & \multirow[t]{2}{*}{3,500} \\
\hline Baik & 12 & 30,0 & 15 & 46,9 & 40 & 100 & & \\
\hline \multicolumn{9}{|l|}{ Dukungan Keluarga } \\
\hline Tidak Terjangkau & 32 & 62,7 & 19 & 3,73 & 50 & 100 & \multirow[t]{2}{*}{0,001} & \multirow[t]{2}{*}{4,884} \\
\hline Terjangkau & 10 & 25,6 & 29 & 74,4 & 40 & 100 & & \\
\hline \multicolumn{9}{|l|}{ Akses Pelayanan } \\
\hline Tidak Terjangkau & 33 & 57,9 & 24 & 42,1 & 57 & 100 & \multirow[t]{2}{*}{0,010} & \multirow[t]{2}{*}{3,666} \\
\hline Terjangkau & 9 & 46,7 & 24 & 53,3 & 33 & 100 & & \\
\hline
\end{tabular}

Sumber : Hasil olah data 2017 
Dari hasil nilai Odd Rasio (OR) $95 \%$ CI adalah sebesar 3,667 (1,448-9,285) yang artinya responden yang memiliki akses pelayanan tidak terjangkau berpeluang 3,6 kali partisipasi pria dalam mengikuti keluarga berencana dibandingkan dengan responden yang memiliki akses pelayanan terjangkau.

\section{Pembahasan}

Interprestasi data yang disajikan dalam bentuk narasi sehingga memudahkan pemahaman terhadap hasil penelitian, yaitu diuraikan bahwa berdasarkan teori yang ada dapat dilihat adanya hubungan persepsi, dukungan keluarga, dan akses pelayanan keselahatan terhadap partisipasi pria dalam keluarga di wilayah kerja Pusksesmas Megamendung Bogor Jawa Barat Tahun 2017.

\section{Hubungan Persepsi dengan Partisipasi Pria dalam Keluarga Berencana di Wilayah Kerja Puskesmas Sukamanah Kec. Megamendung Bogor Jawa Barat Tahun 2017}

Berdasarkan analisis Hubungan Persepsi dengan Partisipasi Pria dalam Keluarga Berencana di Wilayah Kerja Puskesmas Sukamanah Kec. Megamendung Bogor Jawa Barat Tahun 2017 di peroleh sebanyak 30 responden $(60,0 \%)$ dari 50 responden yang memiliki persepsi buruk dengan partisipasi rendah dan ada sebanyak 12 responden $(30,0 \%)$ yang mendapatkan persepsi baik dengan partisipasi tinggi. Hasi uji statistik nilai $\rho$ value $=0,009$ dalam hal ini nilai $\alpha<0,05$ yaitu Ho di tolak dan pernyataan Ha di terima maka akan dapat disimpulkan bahwa ada hubungan antara persepsi dengan partisipasi pria dalam keluarga berencana.

Dari hasil nilai Odd Rasio (OR) 95\% CI adalah sebesar 3,500 $(1,449-8,453)$ yang artinya responden yang memiliki persepsi buruk berpeluang 3,5 kali partisipasi pria dalam mengikuti keluarga berencana dibandingkan dengan responden yang memiliki persepsi baik.

Persepsi adalah proses penambahan ataupun pemberian informasi terhadap stimulasi. Stimulasi didpat dari proses pengindra terhadap objek, pariwisata atau hubungan-hubungan antra segala yang selanjutnya diproses oleh otak. ${ }^{7}$

Sejalan dengan penelitian Saptono Iman Budisantoso Persepsi responden tentang partisipasi pria dalam KB sebagian besar pada kategori cukup yaitu $77 \%$ dan kategori baik sebanyak $12 \%$, sedangkan terendah kategori rendah sebanyak $11 \%$. Berdasar uji statistikdengan uji chi square dengan tingkat kepercayaan $95 \% \quad(\alpha=0,05 \%)$ ternyata ada hubungan yang signifikan antara persepsi terhadap partisipasi pria dalam Keluarga Berencana dengan partisipasi pria dalam Keluarga Berencana dengan $\mathrm{p}$ value $0,009 .{ }^{1}$

Menurut peneliti ini, peneliti berasumsi bahwa persepsi merupakan faktor yang sangat mempengaruhi partisipasi pria dalam KB karena kebanyakan suami berpendapat salah terhadap program Keluarga Berencana dengan alasan resonden yang menyatakan bahwa kondom dapat mengurangi kenikmatan dalam dubungan suami-istri, pelaksanaan akseptor vasektomi membahayakan keselamatan jiwa, menggunakan kondom dilarang agama patner dalam reproduksi sehingga sangat beralasan apabila suami dan istri berbagi tanggung jawab dan peran secara seimbang untuk mencapai keputusan kehidupan seksual dan berbagi beban untuk mencegah penyakit serta komplikasi KB dan kesehatan reprosuksi, suami bertanggung jawab secara sosial dan ekonomi termasuk untuk anak-anaknya, sehingga akan membentuk ikatan yang lebih kuat antara istri dan keturunannya.

\section{Hubungan Dukungan Keluarga dengan Partisipasi Pria dalam Keluarga Berencana di Wilayah Kerja Puskesmas Sukamanah Kec. Megamendung Bogor Jawa Barat Tahun 2017}

Berdasarkan analisis hubungan dukungan keluarga terhadap dengan partisipasi pria dalam keluarga berencana di Wilayah Kerja Puskesmas Sukamanah Kec. Megamendung Bogor Jawa Barat Tahun 2017 yaitu ada sebanyak 32 responden $(62,7 \%)$ dari 51 responden yang memiliki dukungan keluarga tidak mendukung dengan partisipasi rendah dan ada sebanyak 10 responden $(25,6 \%)$ dari 39 responden yang memiliki dukungan keluarga mendukung dengan partispasi rendah.

Hasi uji statistik nilai $\rho$ value $=0,001$ dalam hal ini nilai $\alpha<0,05$ yaitu Ho di tolak dan pernyataan $\mathrm{Ha}$ di terima maka akan dapat disimpulkan bahwa ada hubungan antara dukungan keluarga dengan partisipasi pria 
dalam keluarga berencana. Dari hasil nilai Odd Rasio (OR) 95\% CI adalah sebesar 4,884 (1,954-12,206) yang artinya responden yang memiliki dukungan keluarga tidak mendukung berpeluang 4,8 kali partisipasi pria dalam mengikuti keluarga berencana dibandingkan dengan responden yang memiliki dukungan keluarga mendukung.

Hasi penelitian ini sejalan dengan penelitian Dwi Puspitasari uji statistik nilai $\rho$ value $=0,000$ dalam hal ini nilai $\alpha<0,05$ yaitu Ho di tolak dan pernyataan Ha diterima maka akan dapat disimpulkan bahwa ada hubungan antara dukungan keluarga dengan partisipasi pria dalam keluarga berencana. Berdasarkan nilai OR yaitu 19,085 berarti responden dengan dukungan keluarga yang tinggi memiliki kemungkinan 19 kali lebih besar untuk ikut KB daripada responden dengan dukungan keluarga yang rendah. Nilai koefisien kontingensi sebesar 0,479 menunjukkan tingkat keeratan hubungan antara dukungan keluarga dengan keikutsertaan PUS untuk ber-KB adalah sedang. ${ }^{18}$

Dukungan keluarga merupakan sebuah proses yang terjadi sepanjang masa kehidupan. Sifat dan jenis dukungan berbeda dalam tahaptahap kehidupan. Dukungan keluarga dapat berupa dukungan sosial secara internal seperti dukungan suami, istri atau dukungan dari saudara kandung dan dapat juga berupa dukungan keluarga yang eksternal bagi keluarga inti. Dukungan keluarga membuat keluarga mampu berfungsi dengan berbagai kepandaian dan akal, karena hal ini meningkatkan kesehatan dan adaptasi keluarga. ${ }^{8}$

Peneliti berpendapat bahawa dukungan keluarga juga dapat memegang peran penting dalam partisipasi pria dalam keluarga berencana karena keluarga mempunyai potensi atau faktor penguat yang membuat seorang bertindak terhadap objek tertantu. Namun faktor penguat ini bias bersifat positif dan negatif tergantung sikap dan perilaku pemantau. Hal ini membuktikan hari hasil penelitian di atas yang menunjukan bahawa bagi pasangan usia subur saat ini KB masih merupakan hal yang tabu dan dianggap aneh. Masyarakat masih beranggapan bahwa yang memiliki hak dan kewajiban untuk ber-KB adalah wanita. Hal tersebut yang juga akhirnya mempengaruhi pola pikir keluarga khususnya istri bahwa KB adalah urusan wanita saja dan suami tidak perlu ber-KB. Kesadaran responden dalam mendukung program ber-KB masih rendah, hal ini terlihat dari gambaran data yang diperoleh mayoritas dari responden tidak aktif dalam ber-KB. Faktor kebudayaan lama yang menganggap banyak anak banyak rezeki dan rendahnya pendidikan responden tampaknya masih mempengaruhi responden dalam berperan aktif untuk ber-KB.

\section{Hubungan Akses Pelayanan dengan Partisipasi Pria dalam Keluarga Berencana di Wilayah Kerja Puskesmas Sukamanah Kec. Megamendung Bogor Jawa Barat Tahun 2017}

Berdasarkan analisis hubungan akses pelayanan terhadap dengan partisipasi pria dalam keluarga berencana di Wilayah Kerja Puskesmas Sukamanah Kec. Megamendung Bogor Jawa Barat Tahun 2017 yaitu dari 33 responden (57,9\%) yang memiliki akses pelayanan tidak terjangkau dengan pertisipasi rendah dan ada sebanyak 9 responden $(27,3 \%)$ yang memiliki akses pelayanan terjangkau yang memiliki partisipasi rendah.

Hasi uji statistik nilai $\rho$ value $=0,010$ dalam hal ini nilai $\alpha<0,05$ yaitu Ho di tolak dan pernyataan Ha di terima maka akan dapat disimpulkan bahwa ada hubungan antara akses pelayanan dengan partisipasi pria dalam keluarga berencana. Dari hasil nilai Odd Rasio (OR) 95\% CI adalah sebesar 3,667 (1,448$9,285)$ yang artinya responden yang memiliki akses pelayanan tidak terjangkau berpeluang 3,6 kali partisipasi pria dalam mengikuti keluarga berencana dibandingkan dengan responden yang memiliki akses pelayanan terjangkau.

Hasil penlitian ini tidak sejalalan dengan Saptono Iman Budisantoso hasil uji Chi square diperolah tidak hubungan yang signifikan antara akses pelayanan terhadap partisipasi pria dalam KB dengan partisipasi pria dalam KB. Dengan uji Chi square $(\alpha=0,05)$ didapatkan $\rho$ value $0,133{ }^{1}$

Sejalan dengan hasil penelitian Anton bahwa Hasil uji statistik terhadap hubungan akses pelayanan dengan partisipasi pria PUS dalam memilih metode kontrasepsi didapatkan $\mathrm{p}$ $=0,001<0,05$, hasil ini menunjukkan adanya hubungan yang bermakna antara akses pelayanan dengan partisipasi pria PUS dalam 
memilih metode kontrasepsi. Hasil penelitian menyatakan bahwa adanya kemudahan dan ketersediaan sarana pelayanan ternyata berdampak positif terhadap penggunaan sesuatu alat kontrasepsi. Aksesibilitas pria terhadap informasi mengenai Keluarga Berencana rendah karena masih terbatasnya informasi tentang peranan pria dalam Keluarga Berencana; dan aksesibilitas pria terhadap sarana pelayanan kontrasepsi rendah. Dimana Puskesmas terdapat pelayanan Kesehatan Ibu dan Anak yang umumnya melayani Ibu dan Anak saja sehingga pria merasa enggan untuk konsultasi dan mendapat pelayanan. ${ }^{2}$

Akses pelayanan kesehatan adalah pelayanan kesehatan itu harus dicapai oleh masyarakat, tidak terhalang oleh keadaan geografis, sosial ekonomi, organisasi dan bahasa. Salah satunya yaitu keadaan/deografis dapat diukur dengan jarak, lama perjalanan, jenis tranfortasi dan atau hambatan fisik lain yang mengjalangi seseorang untuk mendapatkan pelayanan kesehatan. demikian pula terbatasnya jumlah sarana pelayanan yang dapat memenuhi kebutuhan pria serta waktu buka sarana pelayanan tersebut. ${ }^{6}$

Menurut penelitian ini, peneliti berasumsi bahwa dari analisis terlihat bahwa Hal ini berbeda dengan penelitian yang menyatakan kemudahan dan ketersediaan pelayanan berdampak positif terhadap penggunaan suatu alat kontrasepsi. Menurut Green faktor akses pelayanan merupakan salah satu faktor pemungkin (enabling) yang menyebabkan seseorang bertindak atau tidak bertindak terhadap suatu obyek tertentu. Akses yang mudah dijangkau ke fasilitas pelayanan yang memadai akan meningkatkan pemanfaatannya dibandingkan dengan yang sulit dijangkau. Karena jika jangkauannya sulit dipikirkan pertimbangan-pertimbangan yang akan dipengaruhi untuk menggunakan fasilitas program keluarga berencana, seperti segi kendaraan, waktu tempuh, sampai, ditempat fasilitas pelayanan dan biaya yang akan dikeluarkan.

\section{Kesimpulan}

Berdasarkan hasil penelitian yang penulis lakukan didapatkan adanaya hubungan yang signifikan antara persepsi, dukungan keluarga, dan kases pelayanan terhadap partisipasi pria dalam keluarga berencana diwilayah kerja Puskesmas Sukamanah Kec. Megamendung Bogor Jawa pada Tahun 2017. Berdasarkan hasil distribusi frekuensi partisipasi pria dalam keluarga berencana sebanyak dari 90 responden yang memiliki persepsi tinggi 48 responden (53,5\%), Persepsi buruk 50 responden $(50,6 \%)$, Dukungan keluarga tidak mendukung 51 responden $(56,7)$, dan Akses Pelayanan tidak mendukung 57 responden(63,3\%), Berdasarkan analisis ada hubungan antara persepsi dengan partisipasi pria dalam keluarga berencana dengan hasil uji statistik nilai $\rho$ value $=0,009$ dalam hal ini nilai $\alpha<0,05$, Berdasarkan analisis ada hubungan antara dukungan keluarga dengan partisipasi pria dalam keluarga berencana dengan hasil uji statistik nilai $\rho$ value $=0,001$ dalam hal ini nilai $\alpha<0,05$, Berdasarkan analisis ada hubungan akses pelayanan terhadap dengan partisipasi pria dalam keluarga berencana dengan hasil uji statistik nilai $\rho$ value $=0,010$ dalam hal ini nilai $\alpha<0,05$, Kesimpulan dari penelitian diatas bahwa persepsi, dukungan keluarga dan akses pelayanan kesehatan sangat mempengaruhi suami dalam partisipasi keluarga berencana karena ada faktor mempermudah, faktor pendorang, faktor pendukung dan sejalan dengan teori yang ada.

\section{Saran}

Bagi Sekolah Tinggi Ilmu Kesehatan Indonesia Maju, diharapkan agar menjadikan hasil penelitian sebagai bahan tambahan referensi pustaka untuk meningkatkan pengetahuan mahasiswa kebidanan.

Bagi Puskesmas, diharapkan untuk terus berkoordinasi dalam hal peningkatan jumlah keder kesehatan yang menangani bidang $\mathrm{KB}$ dan bagi petugas lapangan keluarga berencana (PLKB) untuk lebih aktif mendatangi rumahrumah warga dalam memberi penyuluhan atau penjelasan tentang efek samping yang ditimbulkan oleh alat kontrasepsi, bahwa hal tersebut merupakan hal yang biasa diatasi.

Bagi Responden, diharapkan untuk terus berpartisipasi dalam program KB. Sementara untuk PUS yang belum Ber-KB, diharapkan lebih aktif dalam mengikuti penguluhan tentang KB yang ada di puskesmas atau sekitar lingkungan rumah, mencari informasi tentang $\mathrm{KB}$ baik melalui buku, majalah, internet atau dengan bertanya kepada petugas kesehatan yang 
berada di Puskesmas, sehingga program KB dapat berjalan dengan lancer dan akhirnya dapat terwujudnya keluarga kecil berkualitas.

Bagi peneliti lain, diharapkan untuk menambah variabel penelitian seperti kepercayaan, jumlah anak, peran petugas kesehatan, kualitas pelayanan sehingga faktorfaktor berhubungan dengan partisipasi pria dalam keluarga berencana dapat diketahui lebih dalam lagi.

\section{Daftar Pustaka}

1. Budisantoso S.I. Faktor-Faktor Yang Dengan Partisipasi Pria Dalam Keluarga Berencana (Jurnal) Surabaya: Undip; 2011. www.undip.ac.id, diakses pada bulan juni 2017

2. Anton. Kualitas Pelayanan Keluarga Berencana dan Perspktif Akseptor dan Wilayah Pelayanan BKKBN Kebupaten Jayawijaya. Tesis: Universitas Gadjah Mada; 2010. Diakses pada bulan maret 2017.

3. World Health Development,W.2014. [Online]Availableat:http://www.WHO.ac.id [Accessed september 2016].

4. Bitssream. Repository USU; 2013 http://repository.usu.ac.id/bitstream/123456789/3 4432/5Chapter\%20I.pdf [Accessed 26 Juni 2017].

5. Rismalinda. Psikologi Kesehatan. Jakarta: Anggota IKAPI; 2017.

6. Pohan. Jaminan Mutu Layanan Kesehatan. Jakarta: Graha Ilmu; 2013.

7. Walgito B. Pengantar Prikologi Umum. Yogyakarta: Rikena Cipta; 2013.
8. Friedman. Buku Ajaran Keperawatan Keluarga Riset. Jakarta: Teori Dalam Praktek; 2010.

9. Suharmi A. Dasar-Dasar Evaluasi Pendidik. Bandung: Bumi Aksara Tim; 2010.

10. Agus. Peraturan Gubernur Provinsi Daerah Khusus Ibukota Jakarta Nomor 7. Jakarta: Kantor Gubernur Provinsi Daerah Khusus Ibukota Jakarta; 2017. Diakses pada bulan juni 2017.

11. Sudarmono. Provinsi Jawa Barat dalam Angka Statistik: ( Jawa arat Province in Figures); 2016. Diakses pada bulan Mei 2017.

12. Bachdi RM. Provinsi Jawa Barat. Badan Pusat Statistik Provinsi Jawa Barat: p.174; 2016. Diakses pada bulan 2017.

13. Sulistyaningsih. Metodologi Penelitian Kebidanan Kuantitatif-Kualitatif. Jakarta: Graha Ilmu; 2014.

14. Notoatmodjo S. Promosi Kesehatan dan Perilaku Kesehatan. Jakarta: Rineka Cipta; 2012.

15. Hastono SP. Statistik Kesehatan. Jakarta: Rajawali Pers; 2011.

16. Novita L. Buku Ajar Metodelogi Penelitian Kebidanan. Yogjakarta: Deepublish; 2015.

17. Hasian M. Faktor Yang Berhubugan Dengan Kepesertaan Pria dalam Program Keluarga Berencana di Wilayah Kerja Puskesmas Sei Jang Tanjung Pinang 2012. (Jurrnal) Jakarta: Umpak; 2015.

18. Puspitasari D. Dukungan Keluarga Dalam Keikutsertaan Keluarga Berencana pada Pasangan Usia Subur di Desa Argomulyo Sedayu Bantul Yogyakrta; 2014. Jurnal Ners and Midwife Indonesia. http://lib.ui.ac.id/naskahringkas/Achmad20Dam ayanto, diakses pada bulan februari 2017. 